\title{
Özel Kolluk Kuvveti Olarak Belediye Zabıtası: Zabıtaların Temel Sorunlarının Isparta Ölçeğinde Nitel Bir Analizi ${ }^{1}$
}

\author{
Municipal Police as Private Law Enforcement Force: A Qualitative Analysis of Basic Problems of \\ Municipal Police in Isparta Scale
}

\section{Elvettin AKMAN}

Dr. Öğr. Üyesi, Süleyman Demirel Üniversitesi, İ̈BF, Siyaset Bilimi ve Kamu Yönetimi, elvettinakman@sdu.edu.tr https://orcid.org/0000-0003-2303-840X

\section{Tuğçe BAYRAM}

Arş. Gör. Süleyman Demirel Üniversitesi, İ̈BF,

Siyaset Bilimi ve Kamu Yönetimi, tugcebayram@sdu.edu.tr https://orcid.org/0000-0002-9344-8327
Makale Başvuru Tarihi: 25.12.2018

Makale Kabul Tarihi: 01.01.2019

Makale Türü: Araştırma Makalesi

\begin{tabular}{|c|}
\hline $\begin{array}{l}\text { Anahtar } \\
\text { Kelimeler: }\end{array}$ \\
\hline Yerel Yönetimler, \\
\hline Belediye, \\
\hline Belediye Zabitası, \\
\hline $\begin{array}{l}\text { Özel Kolluk } \\
\text { Kuvveti, }\end{array}$ \\
\hline Isparto \\
\hline
\end{tabular}

Keywords:

Local Governments,

Municipality,

Municipal Police,

Special Law

Enforcement,

Isparta,

\section{ÖZET}

Kentlerde yaşayan nüfusun çeşitli kentsel ihtiyaçlarının karşılanması, yaşam kalitesinin arttırılması ve sürdürülmesi, temel hak ve hürriyetlerin korunarak toplumun refah ve düzeninin sağlanması yerel yönetimlerin temel görevleridir. Bu açıdan halka en fazla hizmeti sunmak ile yükümlü yerel yönetim birimi olan belediyelerin sunduğu hizmetler de büyük önem arz etmektedir. Belediyeler yerel halkın ihtiyaçlarını karşılamakla yükümlü tüzel kişiler olarak, halkın sağlı, esenlik ve refahını sağlama, genel güvenlik hizmetleri dışındaki alanlarda asayiş temini, yerleşim yerinin düzenini koruma ve sürdürme gibi görevlere haizdir ve bu görevlerin önemli bir kısmını belediye zabıtası aracıllğ̆ ile yürütmektedir. Özel kolluk gücü statüsünde görev yapan belediye zabitasl, belediye tarafindan yerine getirileceği belirtilip de mahiyeti itibariyle belediyenin mevcut diğer birimlerini ilgilendirmeyen görevleri de yerine getirmektedir. 5393 sayll Belediye Kanununun 51 'inci maddesine dayanılarak hazırlanan ve 2007 yllında yürürlüğe giren 26490 sayll Belediye Zabıtası Yönetmeliği çerçevesinde belediye zabıtasına oldukça fazla görev ve sorumluluk yüklenmiştir. Yönetmelik incelendiğinde belediyenin düzeni esenliği, imar, sağllk, trafik ve yardımlar ile alakalı ve bu konularda uzmanlık gerektiren 51 adet görevin belediye zabitasına verildiği görülmektedir. Geniş bir görev ve sorumluluk yelpazesi olan belediye zabıtaları, her meslek grubu gibi çeşitli sıkıntılar yaşamaktadır. Bu sorunlar görevlerin yerine getirildiği sırada yaşanan sorunlar olmakla birlikte, mevzuat kaynakl, özlük haklarlyla ilgili, mali, toplumsal, yönetsel, örgütsel, siyasal, personel veya sağllk temelli de olabilmektedir. Belediyelerin hizmet sunumunda ön planda olan birimlerinden zabıtaların yaşadı̆̆ sıkıntılar, Isparta Belediyesi Zabıtası özelinde bu çalışmanın temel konusunu oluşturmaktadır. Çalışmada belediye zabitalarının tanım ve tarihsel gelişimi ile mevzuatta ve uygulamada ki yeri, Isparta Belediyesinde görev yapan zabıtaların genel nitelikleri ve yaşadıkları mesleki sıkıntılar incelenmiş, çalışma çerçevesinde zabıta personeliyle görüşmeler gerçekleştirilmiş ve öneriler sıralanmıştır.

\section{ABSTRACT}

The main tasks of local governments are to meet the various urban needs of the population living in the cities, to increase and sustain the quality of life, protecting the basic rights and freedoms to ensure the prosperity and order of the society. In this respect, the services provided by the municipalities, which are the local administration units that responsible for providng the most services to the public, are also of great importance. As the legal entities liable to meet the needs of the local people the municipalities are responsible for ensuring the health,well-being and prosperity of the people, the protection and the maintenance of the order of the settlement in the areas other than the general security services and a significant portion of these duties are carried out by municipal police. The municipal police, which is working as a special law enforcement power, also fulfills the other duties that mentioned to be fulfilled by municipality, don't concern other existing units of the municipality. Much of the task and responsibility has been assigned to the municipal police in the framework of the 26490 Municipality Police Regulation which prepared on the basis of Article 51 of the Municipal Law No. 5393 and entered into force in 2007. When the

1 Bu çalışma; 1-3 Kasım 2018 tarihleri arasında Alanya'da (ANTALYA) gerçekleştirilen Alanya Uluslararası Yerel Yönetimler Sempozyumunda sözlü olarak sunulmuş ve herhangi bir yerde yayımlanmamış olan bildiri metninin gözden geçirilmiş ve genişletilmiş halidir. 
Regulation is examined, it is seen that the 51 duties which are related to the municipality's order, peace, development, health, aid and traffic and that requiring expertise in these matters are given to the municipality police. The municipal police, which have a wide range of duties and responsibilities, experience various problems like every occupational group.These problems may be the ones experienced when tasks are performed as well as related to personal rights,liegislative, financial, social,administrative, organizational,political,personel or health-related issues. The problems of the municipal police,specific to Isparta, from the units which in the forefront for service delivery are the main subject of this study.In the study, with the definition and historical development of the municipal police, their place in the legislation and practice, the general qualities of municipality police officers working in Isparta Municipality and the professional problems they have experienced are examined, in the framework of the study, interviews were conducted with the municipal police officers and the recommendations were listed.

\section{GİRIŞ}

Şehirleşmenin hızla arttığı günümüzde belediyeler, kendilerine anayasa ve kanunlarla verilen kamusal görevi yerine getirmede çeşitli yetkiler ve bu yetkileri kullandıkları birimlerle donatılmışlardır. Belediye zabıtası teşkilatı bu birimlerin başında gelmektedir ve belediyenin kolluk kuvveti olarak görev yapmaktadır. Beldenin güvenliğinden ziyade huzur ve esenlik sağlamada, imar, sağlık, trafik gibi alanlarda halk sağlığı ve kamu yararı için denetleme, ceza kesme, mühürleme gibi işlemleri yerine getirmektedir. Belediye zabıtasının yetki alanı içinde yer almasa dahi yerel halkın algısında zabıta belde içinde ortaya çıkan tüm sorun ve ihtiyaçların muhatabı konumundadır. Bu durum zabıtanın uzlaştırıcı veya ilgili birimle bağ kuran bir rol üstlenmesiyle sonuçlanmış ve kendi işi olmayan işleri de üstlenmesi normal işleyişte yer etmiştir.

Günümüzde kentlerin sürekli bir değişim ve gelişim halinde olması büyük küçük her kentin ihtiyaçlarının ve niteliklerinin artması anlamına gelmektedir. Bu durum kentlerde yaşayan insanların beledi hizmetlerden beklentisini de etkilemektedir. Daha çağdaş, etkili ve sürdürülebilir hedefler doğrultusunda, kentleri erişilebilir, güvenli ve denetimli bir yaşam alanına dönüştürme hususunda yerel yönetim birimleri de önemli rol oynamaktadır. Kentin esenlik ve huzurunu sağlama, kent halkının gündelik yaşamında etkileşim içinde olduğu olay, olgu, kişi ve kuruluşlarla ilişkilerini düzenleme hususunda etkin olan birimlerin başında belediye zabıtası gelmektedir.

Çalışmaya konu olan Isparta Belediyesi zabıta teşkilatı da mücbir alan dâhilinde yer alan pek çok iş ve işlemi gerçekleştirmektedir. Çalışma kapsamında halk ile iç içe ve iletişim halinde olan bu teşkilatın çalışanlarına mesleklerini ifa ederken karşılaştıkları sorunlar, mevzuat kaynaklı yaşadıkları sorunlar, belediye yönetimi ile aralarındaki ilişkiler, personel rejimi ve mesleki bilgilerini ölçen sorular yöneltilmiştir. Verilen yanıtlar çözümlenerek analiz edilmiştir.

\section{BELEDIYY ZABITASI HAKKINDA GENEL BILLGILLER}

Belediye zabıtas1; "Beldenin düzenini muhafaza eden, belde halkının esenlik, sağglk ve huzurunu koruyan, yetkili organların bu amaçla alacakları kararları uygulayan özel zabıta kuvvetini" ifade etmektedir (Belediye Zabıta Yönetmeliği, m.4). Belediye zabıtası, başkanı ve üyeleri seçimle belirlenen ve bir yerel yönetim birimi olan belediyeye bağlı olarak faaliyet göstermektedir. Belediye Zabıtasının görev, yetki ve sorumluluk alanlar1 5393 sayılı Belediye Kanununun 51. maddesine dayanılarak hazırlanan İçişleri Bakanlığının 26490 Sayılı 'Belediye Zabıta Yönetmeliği’ ile belirlenmiştir. Zabıta teşkilatı, şehirlerde zabıta müdürlüğü adı altında örgütlenerek zabıta müdürü üzerinden doğrudan belediye başkanına bağlıdır, büyükşehir belediyelerinde ise, zabıta dairesi başkanlığı olarak örgütlenir ve zabıta müdürü, zabıta dairesi başkanı, genel sekreter yardımcısı ve genel sekreter üzerinden belediye başkanına bağlanmaktadır.

Belediye zabıtası teşkilatının temelleri 1826 yılında 'İhtisap Nezareti'nin kurulması ile atılmıştır. Nezaretin kurulmasından önce kadı ve onun emri altında bulunan subaşı, böcekbaşı, çöplük subaşısı, mimarbaşı gibi yeniçeri ocağı altında örgütlenen görevliler ile yürütülen denetim ve kontrol işleri, yeniçeri ocağının kaldırılmasından sonra İhtisap Nezaretine geçmiştir (Yeter, 1996:49; Erkul ve Karakılçı1, 2000:89). Başkent İstanbul'da ihtisap nezaretinin yürüttüğü güvenlik ve asayiş hizmetleri, eyaletlerde Sipahiler tarafindan yerine getirilmiştir. 1826-1854 yılları arasında bir takım beledi görevleri de yürüten İhtisap Nezareti, 1845 yılında polis teşkilatının kurulmasıyla zabıta hizmetlerini devretmiş, 1846'da 'Zaptiye Müşiriyeti'nin kurulması ile sadece 
esnafin kontrolü, teftişi ve narh hususlarında faaliyet gösterir olmuştur. Nezaret, 1855 yılında Şehremanetinin ${ }^{2}$ kurulmasıyla da ortadan kalkmıştır (Abay, 2002:6). Cumhuriyet dönemine gelindiğinde ise, zabıtalara düşen görevler ve duyulan ihtiyaç artmıştır. Bu nedenle Fransız Belediye Kanunu model alınarak çeşitli yasal düzenlemeler yapılmıştır (Erbay, 1999:2).

1924 yılında yürürlüğe konulan 417 sayılı Kanun ile başkent Ankara'nın belediyesi yapılandırılmış ve belediye zabıtalığı hizmetleri polis teşkilatınca yürütülmeye başlanmıştır (Karakoyun, 2000:31). Zabıtanın bugünkü statü ve konumunu belirleyen kanun ise 3.4.1930 tarih ve 1580 sayılı Belediye Kanunu olmuştur. Bu kanun ile belediyeler oldukça geniş kapsamlı olarak düzenlenmiştir. 1580 sayılı Belediye Kanunu, 13.07.2005 tarihinde çıkarılan 5393 sayılı Belediye Kanunu ile kaldırılmış zabıta teşkilatı da yeniden düzenlenmiştir. 1580 sayılı Belediye Kanunun 106. Maddesine göre hazırlanmış olan 15.07.1969 tarihli Belediye Zabıta Yönetmeliği ve 12.03.1990 tarihinde Belediye Zabıta Kıyafet Yönetmeliği, 5393 sayılı Belediye Kanununun 51. maddesine istinaden 11.04.2007 tarihinde Resmi Gazetede yayınlanarak yürürlüğe konulan 26490 Sayılı Belediye Zabıta Yönetmeliği ile iptal edilerek, zabıta hakkındaki tüm konular (kuruluş, görev, çalışma, vb.) bu yönetmelikte toplanmıştır (Şimşek, 2016:389).

\section{ISPARTA BELEDIYESİ ZABITA MÜDÜRLÜĞÜNDE BİR ARAŞTIRMA}

Isparta Belediyesi Zabıta Müdürlüğünde görev yapan 40 zabıta personelinden 20'si ile yapılan görüşmelere ilişkin veri ve değerlendirmelere aşağıda yer verilmiştir.

\subsection{Araştırmanın Alanı ve Amacı}

Araştırmanın alanının Isparta Belediyesi Zabıta Müdürlüğünde görev yapan zabıta personeli oluşturmaktadır. Araştırmanın amacı ise, Isparta Belediyesi Zabıta Müdürlügünde çalışan zabıtaların görevlerine ilişkin bilgi ve tutumlarını ölçmek, mesleklerini ifa ederken karşılaştıkları durum ve sorunları incelemek, bu sorunların temelinde yatan mevzuat kaynaklı, belediye yönetimine ilişkin veya farklı bir olgudan kaynaklanan durumları ortaya koymaktır. $\mathrm{Bu}$ amaç ile Zabıta Müdürlüğü bünyesinde çalışan personel ile birebir görüşülmüştür. Nitel araştırma yönteminin kullanıldığı çalışmada, Isparta Belediye Zabıtası ile yarı yapılandırılmış sorular çerçevesinde görüşmeler gerçekleştirilmiştir. Zabıta personeliyle soru-cevap şeklinde yapılan görüşmelerin seyri dâhilinde var olan sorulara ve yapılandırılmış başlıklara ek olarak zabıtaların mesleğe ilişkin öznel sorunları da dinlenmiştir.

\subsection{Araştırmanın Veri Toplama Araçları}

$\mathrm{Bu}$ araştırmada veri toplama yöntemi olarak nitel araştırma tekniklerinden birisi olan yarı yapılandırılmış görüşme yöntemi kullanılmıştır. $\mathrm{Bu}$ yöntem yapılandırılmış görüşmeler gibi katı olmayıp, aynı zamanda yapılandırılmamış görüşmeler kadar da esnek değildir. Her iki yöntemin tam ortasında yer almaktadır (Karasar, 1995:165). Zabıta personeline yönetilecek görüşme soruları hazırlanmadan önce literatür taraması yapılmış ve görüşme formunda yer alması düşünülen sorular belirlenmiştir.

Araştırmaya ilişkin veriler Isparta Belediyesi Zabıta Müdürlüğünde görev yapan zabıta personeli ile 5 Ağustos 2018-15 Kasım 2018 tarihleri arasında görüşülerek toplanmıştır. Isparta il merkezinde 24'ü kadrolu, 16'sı işçi olmak üzere toplam 40 adet zabıta personeli bulunmaktadır. Zabitaların yoğun iş temposu ve personel yetersizliği sebebiyle 40 zabıta personelinden 20'si ile görüşülebilmiştir. Görüşmelerde öncelikle yapılan araştırmaya ilişkin bilgiler verildikten sonra zabıta personeline sorular yöneltilmiştir.

\subsection{Araştırmanın Sınırlılıkları}

Araştırmanın sınırlılıklarını, Zabıta Müdürlüğü bünyesinde çalışan zabıta personelinin sayısının gerekenden çok daha az olması, var olan personelin tamamının değil yarıya yakın bir kısmının memur kadrosunda yer alması, zabıtaların dağınık birimlerde veya gezen ekip olarak çalışması dolayısıyla ulaşılmasının zor olması ve her bir personelin yoğun bir iş temposu dâhilinde çalışması oluşturmaktadır. Zabıta personelinin tamamın memur

216 Ağustos 1855 tarihinde İstanbul'da kurulan günümüz belediye teşkilatının görevlerini yerine getiren kurumdur. Buna göre Şehremaneti halkın zorunlu ihtiyaçlarını karşılamak, şehrin temizlik ve bakımıyla ilgilenmek, yol ve kaldırım yapmak, çarşı ve pazarları denetlemek; daha önce İhtisap Nezaretinin topladığı vergi ve resimleri tahsil edip hazineye teslim etmek gibi görevlere sahip olmuştur (Sunay, 2007:127-128). 
olmayış1, mevzuat ve özlük hakları, görevin getirdiği sorumluluk ve yetki gibi konularda birebir deneyim ile elde edilmemiş, farazi ve gözleme dayalı yorumlar getirilmesi gibi bir kısıt oluşturmuştur.

\title{
4. BULGULAR VE TARTIŞMA
}

Çalışmanın temelini oluşturan Isparta Belediyesi Zabıtası ile yapılan görüşmelerde zabıtalara temel demografik bilgileri ile görevlerine dair bilgiler, görevin ifası sırasında oluşabilecek sorunlar, mevzuat kaynaklı yaşadıkları sıkıntılar ve yönetim ile ilişkilerine dair çeşitli sorular yöneltilmiştir. Zabıta personelinin, personel yetersizliği, alınan ücret, özlük haklarının iyileştirilme gereksinimi gibi konularda hemfikir olduğu, silah taşıma ve zor kullanma yetkisi, belediye yönetimine duyulan güven gibi konularda farklı fikirlere sahip olduğu gözlenmiştir. İş yükünün adil dağıtılması, objektif personel değerlendirmesi, siyasi ilişkiler ve belediye yönetimine dair yöneltilen sorular, zabıta personelinin bir kısmı tarafından çekinceyle cevaplanmıştır.

Görüşülen zabıta personelinin 2'si kadın 18'i erkektir. Görüşülen kadın personelin tamamı, erkek personelin ise 13'ü evlidir. Evli personelin en az 1 en çok 4 çocuğu bulunmaktadır. Eğitim durumuna bakıldığında ilkokul mezunu personelin sayıs 1 , ortaokul mezunu personelin sayıs 1 , lise mezunu personelin sayıs 8 , yüksekokulfakülte mezunu personelin sayısı ise 10'dur. Görüşülen zabıta personeli arasında lisansüstü eğitim alan yoktur. Yaş aralığ 22-54 arasında değişmektedir. Zabıta personelinin büyük bir çoğunluğu daha önce belediyenin farklı birimlerinde çalışmışken, bir kısmı da özel sektör geçmişine sahiptir. Personelin mesleki deneyimleri 1 hafta ile 26 yıl arasında değişmektedir. Meslekte geçirilen yıl kadar, kadro şekli ve derecesine bağlı olarak 2000-2500 TL aralığından başlayan ve 3500-4000 TL miktarına ulaşan bir maaş aralığı bulunmaktadır.

Isparta Belediyesinde çalıştırılan zabıta personeli; memur, kadrolu işçi ve belediye şirketine bağlı işçi olmak üzere üç farklı kadroya sahiptir. Memur olarak çalışan zabıta personeli mevzuatta geçtiği şekliyle, görev, sorumluluk ve yetkiye sahipken işçi kadrosundan gelen ve zabıta biriminde görevlendirilen personel, memur konumundaki personelin yanında destek amaçlı çalıştırılmakta veya yaptı̆̆ iş̧lemlerde memurun adı ve imzasını kullanmaktadır. Bu durum maaş farkları (memur kadrosundaki personel 3000-3500 TL arası, taşeron işçi de denilen şirket işçileri 2000-2500 TL aras1, işçiler ise 3500-4000 TL kimi zaman daha fazla olabilen ücret aralığına sahiptir), yetki ve sorumluluk alma hususunda farklılıklara neden olabilmektedir. Benzer şekilde zabıta personeline yöneltilen sorulara verilen yanıtlarda da bu durumun etkisi gözlenmiştir. Mevzuata yönelik sıkıntıları ölçmek amacıyla sorulan sorularda işçi ve taşeron işçi kadrosunda bulunan personel sorunun doğrudan muhatabı olmadığı için yorum getirmemiş veya kişisel değil genel cevaplar vermiştir.

Zabıtalara yöneltilen soruların ilki, "Isparta il merkezi dâhilinde görev yapan zabıta sayısının yeterli olup olmadiğı" yönündedir. Bu soruyu yanıtlayan zabıta personelinin tamamı personel sayısının yetersiz olduğunu belirtmiş, görüşmenin ilerleyen aşamalarında farklı alanlarda da bu personel yetersizliğinden kaynaklanan sorunlar yaşandığını söylemiştir. Belediye zabıtası yönetmeliğinin 1. maddesine göre;

\begin{abstract}
"Belediye zabıta teşkilatı; 22.02.2007 tarihli ve 26442 sayılı Resmî Gazetede yayımlanan "Belediye ve Bağll Kuruluşlart ile Mahalli İdare Birlikleri Norm Kadro Illke ve Standartlarına Dair Yönetmelik” hükümleri çerçevesinde belediye meclisi kararı ile oluşturulmaktadır. Teşkilat oluşturulurken kaynakların etkili ve verimli kullanılması, zabita hizmetlerinin kalitesinin artırllması, ihtiyaç duyulan nitelik, unvan ve sayıda personel istihdamının sağlanması gözetilir", denilmektedir.
\end{abstract}

Söz konusu Belediye ve Bağlı Kuruluşları ile Mahalli İdare Birlikleri Norm Kadro İlke ve Standartlarına Dair Yönetmelik'te yer alan İl Belediyeleri Norm Kadro Standartları Cetveli'ne göre nüfusu 250.000-299.999 arası olan il belediyelerinde Zabıta Müdürü 1, Zabıta Amiri 8, Zabıta Komiseri 16, Zabıta Memuru 96 adet olmalıdır. TÜİK verilerine göre Isparta merkez nüfusu 2017 yllında 251.531 olarak kaydedilmiştir (biruni.tuik.gov.tr). Buna göre Isparta merkezinde görev yapan zabıta personelinin ilgili yönetmelik bazında yetersiz olduğu söylenebilir.

Belediye zabıta yönetmeliğine göre; belediye zabıtası, hizmetin gereğine ve yoğunluğuna göre, imar, çevre, sağlık, trafik ve turizm gibi kısımlara ayrılabilir (Md. 3). Yapılan görüşmelerden elde edilen bilgilere göre Isparta ili genelinde zabıta teşkilatı, Trafik Şube Müdürlüğü, Ruhsat Şube Müdürlügüu, halk otobüsleri, otogar, köy garajı ekipleri, Zabıta Müdürlüğü yerine Hal Müdürlüğüne bağlı olarak yaş sebze meyve halinde görev alan ekipler, gezen ekipler, şehir içi ve pazar denetimi gibi bölümlere ayrılmış durumdadır. Mesleki anlamda uzmanlaşmayı doğuracak nitelikte bir branşlaşma ise, personel yetersizliği ve il belediyesi olması sebebiyle mümkün olmamıştır. Bu konuda görüşleri alınan zabıta personeli, yukarıda sayılan görev alanlarının bir veya daha fazlasında görev yaptıklarını, kimi zaman görev yerleri arasında geçişlerin olduğunu belirtmiştir. 
Branşlaşmanın mesleki uzmanlaşmada önemini ve gereğini belirten personel, bu gereğin personel yetersizliği sebebiyle ikinci planda kaldığına değinmektedir. Görüşülen bir zabıta personeli;

"Asıl sorun branşlaşma değil, branşlar yeterli ancak personel az, en basit şekliyle Isparta merkezinde bazı günler dört farklı pazar kuruluyor, pazar denetlemesi için ayrılmış personel sayısı ise üç, bu durumda pazarlara yetişmek mümkün olmuyor" demiştir.

Çalışma saatleri bakımından zabıta personeli, hizmetin kesintisiz yürütülmesi için 7/24 çalışmaktadır. Genel anlamda zabıta memurları 657 sayılı Devlet Memurları Kanununda belirtilen çalışma süre ve saatlerine uygun mesai yapmakla birlikte, 6 günde bir nöbet tutmaktadır. Nöbet tutan personele ertesi gün nöbet izni verilmektedir. Ayrıca hafta sonu, bayram tatili, belediye programları, zabıta müdürlüğü çalışması gibi hallerde fazladan mesai yapılmaktadır. Yaş meyve sebze halinde görev yapan zabıta personeli nöbet tutmamaktadır. 24 saat aktif olan hal içerisinde zabıta personeli vardiya usulü çalışmaktadır. 24 saat görev yapan personel görev bitiminden itibaren 48 saat izin kullanmaktadır. Bu vardiyalar içerisine hafta sonu, bayram tatili vb. günler denk gelebilmektedir, böylesi günler çalışma düzenini ekilememektedir. 657 sayılı Devlet Memurları Kanunu'nun 178. Maddesine göre, günlük çalışma saatleri dışında yapılan fazla çalışmalar ücretle karşılanmalı veya fazla çalışmanın her sekiz saati için bir gün (yirmi dört saat) hesabı ile izin verilmelidir. Ancak belediye zabıta yönetmeliğinde;

\begin{abstract}
"Zabıta personelinin çalışma saatleri vardiyalar halinde görevin gereğine göre 24 saat iş 48 saat istirahat veya 12 saat iş 24 saat istirahat şeklinde düzenlenebilir. Belediye zabıta memurlarının haftalık olağan çalışma saatleri 48 saati geçmeyecek şekilde düzenlenir. Ancak, personel sayısı az olan zabitalarda 12 saat iş, 12 saat istirahat şeklinde düzenleme yapllabilir. Bu uygulamadan dolayı hizmetin sürekliliğini aksatmamak kaydlyla ve bir sira dâhilinde personele 657 sayılı Kanunun 99'uncu maddesi göz önünde bulundurularak ayrica haftada bir gün ilave izin verilebilir" (Md. 9/2) denmektedir.
\end{abstract}

Yapılan görüşmelerde nöbet sonrası personele verilen izin süresinin her sekiz saat için on altı saat şeklinde olduğu görülmüş̧ür. Bu durumun zabita personelinin eksikliği neticesinde gerçekleştiği belirtilmiş̧tir.

Hizmet içi eğitim veya mesleğe hazırlık eğitimi konusunda, zabıta personelinin büyük bir kısmının hiç eğitime katılmadığı, eğitim alanlarında Türkiye Belediyeler Birliği'nce düzenlenen eğitimlere katıldığı, katılanların kısa süreli ve bir kereden fazla olmamak kaydıyla eğitim aldığı görülmüştür. Ülkemizde dağınık olarak yürütülen hizmet içi eğitim faaliyetleri, mali sıkıntılardan veya personel sıkıntısından ötürü istenilen ölçüde yarar sağlayamamaktadır. Ama genel olarak eğitimlerin sistematik olarak tek merkezli yürütülememesi sorunun ana kaynağını oluşturmaktadır. Söz konusu kısıtlar belediyelerde eğitim konusunun ihmal edilmesine yol açmaktadır (Negiz, 2007:213).

Görüşülen zabıta personelinden dördünün hizmet içi eğitim aldığı ve alınan eğitimin mesleğe girişte hazırlık niteliği taşıyan bir eğitim olmadığı belirtilmiştir. Halde çalışan zabıta personeli 2012 yılında 2 sefer ve 2013 yılında bir sefer olmak üzere yeni çıkan Hal Yasasını anlatmak ve Hal Kayıt Sistemini öğretmek için Gümrük Bakanlığ 1 tarafından düzenlenen eğitime katılmışlardır. 2015 yılında bir adet hal zabıtası Türkiye Belediyeler Birliği'nce düzenlenen bir diğer hal yasası seminerine katılmış, 3 gün süren seminer boyunca mevzuat hakkında bilgiler verildiğini, belediye ile kurulan ilişkiler, personel, teçhizat konularında fikir alındığını belirtmiştir. Görüşülen personelin tamamına yakını meslek içi eğitim almak istediğini belirtirken, iş yoğunluğu ve personel yetersizliği gibi nedenlerden ötürü eğitime katılmanın görev yapılan ilde verilmediği takdirde çok mümkün olamayacağı belirtilmiştir.

Zabita personeli toplumun genel algisinda ceza kesen, esnaf ve seyyar satıcıları korkutan, gecekondu yıkımlarında vatandaş ile kavga eden, siyasal bir örgütün kamu görevlisi olarak hareket eden çalışanlar olarak görülmektedir. Toplumun zabıtanın görev alanı ile belediyenin görev alanını ayırt edememesi ve zabıtayı belediye tüzel kişiliğinin temsilcisi olarak görmesi de bir diğer sorundur (Pektaş, 2003:106). Isparta toplumunda zabıtaya yönelik tutum ve tavrı ölçmeye yönelik sorulara aldığımız karşılık ise, bu tutum ve tavırların toplumun çeşitli kesimlerine göre şekillendiği yönünde olmuştur. Zaten geniş olan görev tanımına ek olarak farklı birimlerin şikâyetlerinin de zabıtaya yapılması ve diğer kolluk kuvvetlerinin belediye sınırları içinde ortak olan görevleri doğrudan zabıtaya yüklemesi gibi sıkıntılar da mevcuttur. Görüşmeler sonucu zabıtalar, işlerini ifa ettikleri sırada tutanak tuttukları, ikaz, ihtar veya ceza yazdıkları kesimde olumsuz bir algı oluştuğunu ancak toplum faydası düşünüldügünde daha geniş bir kesimde olumlu bir algı oluştuğu, memurların ve halkın 1lımlı 
tavırları sayesinde yaşanan sıkıntıların üstesinden gelindiğini belirtmiştir. Görüşülen zabıta personeli arasından henüz 3 aydır meslekte olan bir zabita personeli;

"Zabıtalık yapacağımı söylediğimde dikkatli ol, adil ol gibi söylemlerle karşılaştım. Ancak bu durum medya tarafindan da olumsuz yönlendiriliyor, zabita ile muhatap olmayan insanlarda dahi olumsuz bir algı olabiliyor" demiştir.

Zabıta personelinin hem fikir olduğu sorunların bir diğeri de yıpranma payı hakkının olmamasıdır. Büro içi ve büro dişı, yirmi dört saat esaslı çalışan, riskli ve tehlikeli görevler ifa eden, fiziki ve zihnen yoğun çalışma yapan ve sürekli tehlike altında olan, belediyenin kanun, nizam ve yasaklarına aykırı davranan kişilerle karşı karşıya gelen ve çoğu kez sözlü ve fiili saldırılara uğrayan zabıta memurları belediyede çalışan diğer personele oranla fiziki ve ruhsal olarak daha fazla yıpranmaktadır. Bu yıpranmanın karşılanması bakımından ilgili kanuna bir ek olarak zabıtaya 'fiili hizmet zammı' verilmelidir (Kırmızı, 2017:121). Görüşülen personel zabıtanın "şehir polisi" olduğunu belirtmiş ve bu sebeple polislere verilen yıpranma payının zabıtalara da verilmesi gerektiğini söylemiştir.

Yıpranma payı hakkında hem fikir olan zabıta personeli silah taşıma ve zor kullanma yetkisi ile şehitlik ve gazilik hakkının bulunmayışı bakımından farklı görüşler belirtmiştir. Can güvenliğini tehdit eden durumlarla sıkça karşılaştıklarını ifade eden zabıta personeli genelde büro dışı çalışan personel olmuştur ve zor kullanma ya da silah taşımamanın kendilerini tehlikeye attığı, kolluk desteği gelene kadar çok geç olabileceği, silahın caydırıcı etkisinin olacağı gibi sebepler öne sürmüş̧ür. Büro dışı çalışan personelin bir kısmı silah taşımayı ve zor kullanma yetkisini gerekli görmemektedir. Bu konuda ki fikirler, "polis yeterli desteği sağllyor, maşa varken elinizi ateşe sokmaya gerek yok" ve "eline silah geçse ilk günden birini vuracak insanlar da zabita olarak çalışlyor" gibi söylemler ile ifade edilmiştir. Yine büro dışı çalışan zabıta personeli şehitlik ve gazilik hakkının vazgeçilemez olduğunu belirtmiştir. Büro içi çalışan veya idari amir konumunda olan zabıtalar ise, silah taşıma veya zor kullanma yetkisinin şart olmadığını veya belli işlerin ifası sırasında taşınması gerektiğini söylemiştir. Büro içi çalışan personelin bir kısmı şehitlik ve gazilik haklarının olmayışını ciddi bir eksiklik olarak görmese de verilmesini olumlu karşılarken bir kısmı gerekli görmediğini belirtmiştir.

Görüşülen personelin büyük bir kısmı silah taşımada psikolojik değerlendirme ve eğitim gibi ön şartların olması gerektiğini de eklemiştir. Ankara'da yapılan 1. Zabıta Çalıştay'ının sonuç bildirgesinde de bu husus;

"Zabıta çalışanlarının çalışma ortamlarında çeşitli sıkıntılar yaşanmaktadır. Bunların bir kısmı uygulama sırasında yaşanan saldırlar, darplar olmakta zabıtalar uğradı̆̆ saldırılarda ölmekte ve yaralanmaktadır. Mevcut yönetmelikteki savunma amaçlı teçhizat olarak önerilenler yetersizdir. Savunma amaçlı teçhizatlara, güvenliği sağlayacak yönde yeni hükümler konulmalıdır" (1. Zabıta Çalıştayı Sonuç Bildirgesi, 2015:Md. 5) şeklinde ele alınmıştır.

Zabıta teşkilatında rütbelerin görevde yükselme sınavı yapılmadan, vekâleten ve liyakate bakılmaksızın verilmesi Isparta Belediyesi Zabıtasında bir diğer sorundur. Görüşmeler sonucu rütbe ve görevde yükselmenin geçici görevlendirmelerle yapıldığı, Belediye Başkanının inisiyatifinde olduğu ve uzun süredir görevde yükselme sınavının açılmadığı görülmüştür. Uzun yıllardır zabıta olarak çalışan bir memur;
"1992'den beri görevde yükselme sınavı açılmıyor, komiser veya amir olanlar, rütbesi yükseltilenler asaleten değil vekâleten atanıyor. Atamalarda yaş, deneyim veya eğitime bakılmıyor. Belediye kendisine yakın olan personeli vekâleten atıyor. Aslında vekâleten atanmak o şekilde atanan personele de haksızlı zira maaşına ya da emekliliğine bir katklst yok, asaleten atansa o da hayrını görecek yani belediye kendi adamı olarak gördüğü çalışanına da çok duyarlı değil. Atamaların taraflı yapılması, haksızlık edilen personeli küstürüyor, açılama istediğimiz de ise "sinavla yükselmeyi hak eden bizden olmayan biri olursa ne olacak?" gibi bir cevapla karşılaşıyoruz. Kısaca biz rütbeyi rüyamızda aldık" şeklinde durumu özetlemiştir.

Her ne kadar Belediye Zabıta Yönetmeliğinin 23. Maddesinde görevde yükselme sınavı ve şartları belirtilse de idare bir kadroya atama yapıp yapmama hususunda takdir yetkisine sahiptir. Bu nedenle ihtiyaç halindeki kadrolara geçici görevlendirme ile amir atanabilmektedir. Bu konuda Kamu Denetçiliği Kurumu'na 15.11.2015 tarihinde yapılan bir şikâyet üzerine açıklanan 22.04.2016 tarihli ve 2015/5347 sayılı emsal bir kararı bulunmaktadır. Tavsiye niteliğindeki karar, 2000 yılından beri meslekte yükselme sınavı açmayan bir belediyenin zabıta personelince şikâyet edilmesi üzerine alınmıştır ve "geçici ve istisnai olarak başvurulacak bir yol olan görevlendirmenin sürekli hale getirilerek 2000 yılından bu yana uygulandiğl, bu nedenlerle kariyer ve liyakat ilkelerine aykırı olarak memurların sınıfları içinde en yüksek derecelere kadar ilerleme imkânının kısıtlanması sonucunu doğuran görevde yükselme sınavı açılma talebinin reddi işleminin idarenin planlanan bir 
görevde yükselme sınavının bulunmadı̆̆ açılklaması da dikkate alınarak hukuka ve hakkaniyete aykırı olduğu sonuç ve kanaatine varılmıştır", denilmektedir (KDK, 2016:6).

Zabıta personeline yöneltilen "görev sırasında karşılaştığınız en önemli beş güçlük nedir?" sorusuna verilen cevaplarda "siyasi baskı" ilk sırada yer almaktadır. Bunu, esnafın ve seyyar satıcıların direnişi, can güvenliğinin olmayışı, vatandaşın olumsuz tavrı (küçümseme, saygısızlık, kural tanımazlık) ve personel yetersizliği izlemektedir. Zabıtanın yerine getirdiği yasaya uygun işlemlerin belediye tarafından akraba, eş dost, tanıdık veya siyasi temelli kayırma sebebiyle iptal edildiği haller zabıtalar için pek çok olumsuzluk doğurmaktadır. Böylesi durumlarda zabıtalar hem yaptıkları iş konusunda tatminsizlik ve umutsuzluk yaşamakta, hem de ceza alması gereken kişi illegal şekilde işini gördürmüş olduğu için zabıtaya saygısız ve kışkırtıcı yaklaşmaya cesaret edebilmektedir. $\mathrm{Bu}$ durumla karşılaşan zabitalar belediyenin bu ve benzer eylemlerini eleştirmekle birlikte durumun değişeceğine dair inanç taşımadıklarını da belirtmiştir.

Belediye yönetiminin değişmesinin, zabıta personeli üzerinde siyasi baskı oluşturduğu gibi, zabıta personelinin mesleğini ifa ettiği durumlarda önüne bir engel olarak çıtığı durumlar da sıkça yaşanmıştır. Zabıtanın toplum nezdinde polis veya jandarma gibi itaat edilmesi zorunlu bir kolluk kuvveti olarak görülmemesi, itibar gören bir kamu denetçisi veya memuru olarak sayılmaması, aslen bir kolluk kuvveti olan zabıtanın hak ettiği değeri ve itibarı görmemesi ile sonuçlanmaktadır.

Zabıta personelinin cevaplamakta çekimser kaldığı soruların başında görevlerini ifa ettikleri sırada yaşadıkları bir sorun karşısında belediyeden destek bulup bulmadıkları sorusu gelmektedir. Cevaplayan personelin bir kısmı hukuki destek ve sağlık desteği almayı gerektiren durumlar yaşadıklarını ve belediyenin bu konuda yardımcı olduğunu ifade etmiş, başka bir kısmı destek gerektiren bir durum yaşasalar belediyenin yardımcı olacağına inandıklarını belirtmiştir. Bir kısım personel ise adli olaylarda tek başlarına bırakıldıklarını söylemiştir. Zabıtalar belediyenin kolluk kuvveti olarak çalıştıkları esnada kamu adına kamu nizamını sağlamaya uğraşmaktadırlar. Bu sebeple 5393 sayılı belediye kanununun 51. maddesinde "Görevini yaparken zabıtaya karşı gelenler, kolluk kuvvetlerine karşı gelenler gibi cezalandırılır" hükmüne göre işlem yapılması ve belediyenin de bu tarz vakalar yaşayan her bir zabıta memuruna gerekli desteği verecek yönetmelik, genelge vb. hükümler vermesi gerekmektedir. Bu duruma benzer çalışmalarda da değinilmiştir. Erkul ve Karakılçık (2000:97);

\section{"Belediye zabitası memurları, görev sirasında, görevden kaynaklanan ve mahkemelik olan konularda belediyeler tarafindan hukuki anlamda yalnız birakllmaktadır. Görevden kaynaklanan sorunlarda belediye avukatlart mahkemelerde zabita memurlarinı savunmalı ve onlar görevlerinde yalnız bırakmamalıdır. Bu amaçla zabıta teşkilatı bünyesinde bir 'hukuk bürosu' oluşturulmalıdır", şeklinde ifade etmiştir.}

Görüşülen zabıta personelinin yarısından fazlası iş tatminini ölçmek amacıyla sorulan objektif performans değerlendirmesi, adil iş yükü dağılımı, çalışanların eşit haklara sahip olması ve alınan ücretin yeterli olup olmadığına dair sorulara olumsuz yanıt vermiştir. Nöbet dağıtımında rütbe vb. değişkenlere çok önem verilmeden nispeten adil bir yöntem izlendiği genel kabul olsa da belli bir kesim zabıtanın diğer zabıta personeline göre daha çok "tutulduğu" ifade edilmiştir. Bu durumun iş bölümü, eşit haklara sahip olma veya objektif değerlendirmeye tabi olma gibi halleri etkilediği kimi personelce ifade edilmiştir. Özellikle belediye ile yakın ilişkilerde bulunan personelin rütbesinin yükseltilmesi ve nispeten rahat kısımlarda çalışmaları, hak ettiği rütbeyi alamayan, daha zorlu şartlarda görev yapan personel tarafindan taraflı ve adaletsiz bir durum olarak değerlendirilmiştir. Bu durumu kıdemli bir zabıta memuru; "Belediyede çalışanın işi, çalışmayanın yevmiyesi artar" diyerek özetlemiştir. Bunun dışında "çalışana hakkı verilir", "herkes çalışlyor, işten kaçan da olmaz, iş verilmeyen de" gibi fikirler de beyan edilmiştir. Fazla mesai yapan zabıtaların bir kısmı, belediyenin ücret hesaplamasında adil olmadığını veya hak ettikleri fazla mesai ücretinin tamamını almadıklarını belirtmiştir. Kadro durumunda yaşanan çeşitlilik nedeniyle (memur, iş̧̧i, taşeron iş̧̧i) maaşların değişmesi hemen hemen tüm personelin adaletsizlik olarak değindiği bir konudur. Özellikle işçiden az alan memur kadrosunda ki zabıta personelinin tüm sorumluluk ve resmi yetkiyi üstlenmesi göze çarpan en büyük eşitsizliktir.

Zabıta personelinin belediyeden beklentisini ölçmek için yöneltilen sorulara verilen cevaplar ise şu şekilde olmuştur; liyakat esasına göre davranılması, işini yapan zabıtaya destek olunması, yetki karmaşası ve siyasi baskının azaltılması, personeli anlamaya dönük faaliyetlerde bulunulması, özel hastaneler ile sağlık anlaşması, tatil, ödül, ikramiye gibi imkânların sağlanması ve bunların adil şekilde dağıtılması olarak sıralanmıştır. Bu beklentiler üst düzey memur ve idari işleri gerçekleştiren memurlarda personel eksikliğinin giderilmesi, araç ve teçhizat teminatının sağlanması şeklinde öne çıkmaktadır. 
Son olarak zabıtaların görevleri yaptıkları sırada en sık kullandıkları mevzuat sorulmuştur. Mevzuatta belediye zabıtasını doğrudan görevlendiren hükümlerin bulunduğu pek çok kanun ve yönetmelik bulunmaktadır. Zabıta personelinin verdiği cevaplarda ilk sırayı Belediye Zabıta Yönetmeliği almıştır. 5393 Sayılı Belediye Kanunu, 5326 Sayılı Kabahatler Kanunu bu cevabı izlemiştir. Cevaplayan zabıtanın yaptığı işe göre çeşitli kanunlar sıralanmıştır. Büro dışı görev yapan zabıta memurları, 2872 Sayılı Çevre Kanunu, 2918 Sayılı Karayolları Trafik Kanunu, 5543 İskân Kanunu, 3194 Sayılı İmar Kanunu, 5957 Sayılı Sebze ve Meyveler ile Yeterli Arz ve Talep Derinliği Bulunan Diğer Malların Ticaretinin Düzenlenmesi Hakkında Kanun, 1608 Sayılı Umuru Belediyeye Müteallik Ahkâmı Cezaiye Hakkında 486 Numaralı Kanun gibi kanunları kullandıklarını belirtirken, büro içi çalışan zabıta memurları ilk sırada yer alan cevaplarına ek olarak İ̧yeri Açma ve Çalışma Ruhsatlarına İlişkin Yönetmelik, 2559 Sayılı Polis Vazife ve Salâhiyet Kanunu, 634 Sayılı Kat Mülkiyeti Kanunu gibi yasa ve yönetmelikleri sıralamıştır.

\section{SONUÇ VE DEĞERLENDİRME}

Belediye zabıtasınca denetlenen alanda yaşanan değişim ve büyüme sonrası, zabıtanın sorumlulukları ve üzerine düşen görevler de artmıştır. Osmanlı'dan günümüze kadar uzanan belediye zabıtası, görev yaptığı ilde genel güvenliğini sağlamaktan ziyade beldenin düzenini sağlayan, belde halkının esenlik, sağlık ve huzurunu koruyan bir kolluk kuvveti olmuştur. Aslen 657 Devlet Memurları Kanununa tabi olan belediye zabıta görevlileri, yıpranma payı, şehitlik, gazilik gibi haklardan, meslekte profesyonelleşmeyi getirecek olan zabıta okulları ve meslek içi eğitimden mahrum durumdadır. Mevzuatta yer alan eksikler de zabıta personelinin genel durumunu kötüleştirmektedir.

Zabıta personeli, görev yaptığı beldede halk sağlığı ve düzeni için denetleme, mühürleme ve diğer kolluk kuvvetleri ile birlikte ortak programlara katılma gibi pek çok alanda yer almaktadır. Yasada yer almayan durumlarda dahi belediyenin halka bakan yüzü konumunda olan zabitalar ilk muhatap alınan birim durumundadır ancak gerek belediyenin siyasal bir kurum olarak görülmesi ve zabıtanın yaptırımının ciddiye alınmaması neticesinde ciddiye alınmama, küçümsenme ve takdir edilmeme gibi durumlar yaşanmaktadır. Bu durumun bir diğer sebebi de kuşkusuz zabıtalığın profesyonel bir meslek olarak görülmemesidir. Bu konuda zabıtalık alım şartlarının düzenlenmesi, zabıta okullarının açılması ve yaygınlaştırılması, meslek içi eğitimlerin yaygınlaştırılması ve zabıtalık mesleğinde yükselme sınavlarının zorunlu hale getirilmesi hem mesleğin itibarını hem de toplumsal imajinı olumlu hale getirecektir.

Isparta Belediyesinde görev yapan zabıtalar ile gerçekleştirilen görüşmelerde zabıta personelinin bu ve benzer konularda sıkıntılarına değinilmek istenmiştir. Görüşülen zabıtaların hemen hepsi personel yetersizliğine değinmiştir. Tek başına önemli bir sorun olmamakla birlikte personel eksikliği pek çok diğer sıkıntının da ikincil sebebi durumundadır. Yıpranma payı haklarının bulunmayışı ise, görüşülen personelin hem fikir olduğu bir diğer sıkıntıdır. Bunları ücret yetersizliği ve meslekte yükselmenin takdir yetkisine bağlı olması izlemektedir.

Yapılan görüşmelerde gezici ekip olarak büro dışında çalışan zabıta personelinin zor kullanma ve silah taşıma, araç ve teçhizat yetersizliği, siyasi baskılarla görevlerini yapmalarının engellenmesi, esnaf, seyyar satıcı ve dilencilerle çatışma, değer görmeme gibi konularda yoğunlaşan şikâyetleri olduğu gözlemlenirken, büro içi, idari ve üst kademe çalışanlarının personel eksikliği, zabıtanın çalıştığı alanlarda uzman olan meslek gruplarının (mühendis, veteriner vb.) teşkilat yapılanması altında bulunması gerektiği fikri, tatil, ikramiye ve ödül gibi beklentiler öne çıkmaktadır. Isparta özelinde yaşanan bu sorunlar ve ortaya çıkan beklentilerin ülke genelinde olma olasılığının yüksek olması dikkate alınarak çözüm için gerekli yasal ve kurumsal adımların atılması gerekmektedir. 


\section{KAYNAKÇA}

1. ZABITA ÇALIŞTAYI (2015), "Sonuç Bildirgesi", 1. Zabıta Çalıştayı Kitabı, 03-04 Eylül 2015, Ankara.

ABAY, Ali Rıza (2002), "Toplumsal Yapı ve Toplumsal Kurum Değişmesi (İhtisap Kurumunun Zabıta Teşkilatına Dönüşümü Örneği)”, Dumlupınar Üniversitesi Sosyal Bilimler Dergisi, S.7, ss.1-17.

ERKUL, Hüseyin ve KARAKILÇIK, Yusuf (2000), "Belediye Zabitasının Örgütsel Yapısı, Sorunları ve Kentsel Yaşam Kalitesine Etkilerinin İrdelenmesi”, Çağdaş Yerel Yönetimler Dergisi, S.9(4), ss.86-105.

ERBAY, Yusuf (1999), “Fransa'da İdari Sistem ve Yerel Yönetimler”, Çağdaş Yerel Yönetimler Dergisi, S.8, ss.58-74.

KARAKOYUN, İsmail (2000), “Kent Zabitast”, İdarecinin Sesi Dergisi, S.14, ss.1-80.

KARASAR, Niyazi (1995), Bilimsel Araştırma Yöntemi, 3A Araştırma Eğitim Danışmanlık Yayını, Ankara.

KDK - T.C. KAMU DENETÇİLIĞİ KURUMU (2016), T. C. Kamu Denetçiliği Kurumu (Ombudsmanlık) Şikâyet ve Değerlendirilmesi, (Şikâyet No: 2015/5347, Karar Tarihi: 22.04.2016).

KIRMIZI, Bilal (2017), "Bir Kolluk Kuvveti Olan Belediye Zabitasi Personelinin Temel Sorunlari ve Bu Sorunlara Getirilen Çözüm Önerileri”, Yüksek Lisans Tezi, İzmir Kâtip Çelebi Üniversitesi Sosyal Bilimler Enstitüsü Küresel Yönetişim ve Siyaset Anabilim Dalı, İzmir.

NEGİZ, Nilüfer (2007), "Belediye Personelinin Hizmet Iç̧i Eğitim Sorunu: Bir Araştırma ve Model Önerisi”, Süleyman Demirel Üniversitesi İktisadi ve İdari Bilimler Fakültesi Dergisi, S. 12(3), ss.193-214.

PEKTAŞ, Ethem Kadri (2003), "Belediye Yönetiminde Zabıta Hizmetleri ve 21. Yüzyll Kentinde Zabıtanın Yeri (Afyon Belediyesi Örneği)”, Doktora Tezi, Dokuz Eylül Üniversitesi Sosyal Bilimler Enstitüsü, İzmir.

TÜİK - TÜRKIYE İSTATISTIK KURUMU (2018), "Adrese Dayalı Nüfus Kayıt Sistemi Sonuçları", E-Rapor, TÜİK Yayın1, Ankara. https://biruni.tuik.gov.tr/medas/?kn=95\&locale=tr (Erişim Tarihi: 10.08.2018).

SUNAY, Cengiz (2007), "Belediyeciliğin Doğuşu Sürecinde Osmanlı Mirası", Kocaeli Üniversitesi Sosyal Bilimler Enstitüsü Dergisi, S.3(1), ss.113-133.

ŞİMŞEK, Savaş (2016), "Belediye Zabita Örgütünün Örgütsel ve İşlevsel Gerekliliği Üzerine Bir İnceleme", Kırıkkale Üniversitesi Sosyal Bilimler Dergisi, S.6(2), ss.387-406.

YETER, Enis (1996), "Belediye Zabıtası ve Personeline İlişkin Düşünceler", Çağdaş Yerel Yönetimler Dergisi, S.5(4), ss.49-55.

657 Sayılı Devlet Memurları Kanunu (23.07.1965 tarih ve 12056 sayılı Resmi Gazete).

5393 Sayılı Belediye Kanununa Ek İçişleri Bakanlığı Belediye Zabıtası Yönetmeliği (11.04.2007 tarih ve 26490 say1lı Resmi Gazete).

Belediye ve Bağlı Kuruluşları İle Mahalli İdare Birlikleri Norm Kadro İlke ve Standartlarına Dair Yönetmelik (22.02.2007 tarih ve 26442 say1lı Resmi Gazete). 